Original Article

\title{
EVALUATION OF ANTI-INFLAMMATORY ACTIVITY OF MACROALGAE COLLECTED FROM BAJA CALIFORNIA SUR, MEXICO
}

\author{
ELENA BERENICE GARCÍA-LÓPEZ1 ${ }^{1}$ MAURICIO MUÑOZ-OCHOA ${ }^{*}$, CLAUDIA J. HERNÁNDEZ-GUERRERO1* ${ }^{*}$, \\ ANTONIO NIETO-CAMACHO ${ }^{2}$, CHRISTINE J. BAND-SCHMIDT ${ }^{1}$
}

${ }_{1}^{1}$ Instituto Politecnico Nacional, Centro Interdisciplinario de Ciencias Marinas. Av. IPN s/n. Col. Playa Palo de Santa Rita, C. P. 23090 , La

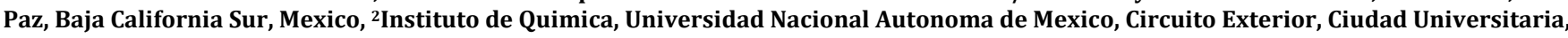
04510 Coyoacan, D. F., Mexico

Email: mmunozo@ipn.mx

Received: 16 Mar 2021, Revised and Accepted: 12 Jun 2021

\section{ABSTRACT}

Objective: This study aimed to establish the anti-inflammatory potential of macroalgae from Baja California Sur, Mexico.

Methods: The anti-inflammatory activity of the extracts from 10 macroalgae species was evaluated in vitro and in vivo. Dichloromethane, ethanolic and aqueous extracts were obtained from each species. The criteria used to determine anti-inflammatory activity included 1) the membrane protection of human red blood cells (HRBCs) against hemolysis induced by hypotonicity, 2) the inhibition of heat-induced protein denaturation (IDP), and 3) the inhibition of mouse ear edema and the myeloperoxidase (MPO) enzyme.

Results: The dichloromethane extracts of Gracilaria vermiculophylla and Opuntiella californica were the most active, both in vitro and in vivo. These extracts resulted in values of HRBC membrane protection above 95\%, which were similar to those obtained with diclofenac sodium. And reduce the inflammation with edema inhibition percentage up to $60 \%$ while the control indomethacin was able to inhibit edema by $82.3 \%$.

Conclusion: The bioprospection of several macroalgae species from Bahía de La Paz, Mexico, allowed the identification of two species with promising anti-inflammatory activity. Gracilaria vermiculophylla showed interesting topical anti-inflammatory effects and a profile of compounds (flavonoids and terpenes) that may contribute to the potential biological properties of this seaweed. This study represents the first report of the anti-inflammatory potential of $O$. californica.

Keywords: Anti-inflammatory, Edema, Gracilaria, Laurencia, Opuntiella, Seaweed

(C) 2021 The Authors. Published by Innovare Academic Sciences Pvt Ltd. This is an open access article under the CC BY license (https://creativecommons.org/licenses/by/4.0/) DOI: https://dx.doi.org/10.22159/ijpps.2021v13i8.41453. Journal homepage: https://innovareacademics.in/journals/index.php/ijpps.

\section{INTRODUCTION}

Inflammation is a response of live tissues to injury, infection, or irritation. Lysosomal enzymes are released during the inflammatory response, leading to a variety of disorders that result in tissue injury due to macromolecule damage and membrane lipid peroxidation, which are assumed to be partly responsible for certain pathological conditions, such as heart attacks or rheumatoid arthritis. In recent years, chronicdegenerative diseases involving various inflammatory processes have displaced infectious diseases as the leading causes of death worldwide [1]. Anti-inflammatory treatments involve the use of steroidal and nonsteroidal drugs. Glucocorticoids like cortisol, which are steroidal, inhibit the transcription of proinflammatory genes and suppress the immune response [2]. On the other hand, non-steroidal agents (e. g., diclofenac sodium) suppress the activity of the cyclooxygenase (COX) enzyme. However, the use of these agents has been associated with gastrointestinal complications and renal insufficiency [3].

The high incidence of chronic diseases associated with inflammation and the adverse effects associated with many commonly used drugs have guided research efforts to identify new sources, active principles and structures that are both highly effective and able to safely control the harmful effects of inflammation. Marine ecosystem contains more than $80 \%$ of the plant and animal species on the planet, which have evolved various adaptive abilities to cope with the continual stress present in their environmental. This has allowed researchers to tap into seemingly inexhaustible marine sources for the development of agents with diverse biopharmaceutical applications [4].

In this context, macroalgae have been reported to produce secondary metabolites that can be used to either prevent inflammation or protect cells from damage due to inflammatory reactions. Macroalgae constitute a natural source of active compounds with structural characteristics that confer highly effective pharmacological properties. The biological activities of macroalgal extracts have different mechanisms of action, including free radical sequestration, electron donation and acceptance, phospholipase A2 or DNA polymerase inhibition, and the formation and/or release of prostaglandins and leukotrienes [5-7].

Studies on the pharmacological potential of the algal resources from the Baja California peninsula are scarce; however, some evidence of the potential of these resources has been collected. For example, in 1974, a group of researchers on board the oceanographic vessel Alpha Helix ventured into the Mexican Pacific and the Gulf of California in search of antibacterial, cytotoxic, and antiviral compounds of pharmacological interest. For this purpose, 181 samples of macroalgae were evaluated against various microorganisms (bacteria and yeasts), cell lines (VERO, KB, and L1210), and herpes simplex virus HSV-1 [8]. Without a doubt, this expedition opened a window of opportunity into the study of novel molecules. Even though the coastal marine regions from southern California to Baja California Sur and the Gulf of California have a collective algal richness of around 900 species, the pharmacological or industrial uses of these marine algae have not been fully studied. In recent years, the number of bioprospecting studies of macroalgae from the Gulf of California and the coasts of Baja California Sur has increased. These studies have focused on evaluating the antibacterial, anticancer, insecticide, and antifouling properties of macroalgae in addition to their ability to inhibit enzymes and their possible uses as biofertilizers or biostimulants for plant growth and have found promising results [9-16]. Therefore, in the present study, an evaluation of the anti-inflammatory activity of marine macroalgae extracts was carried out to identify species with great potential.

\section{MATERIALS AND METHODS}

\section{Algae collection and extracts}

Macroalgae were collected from the subtidal zones of San Juan de la Costa and Punta Roca Caimancito, which are located in Bahía de La 
Paz, Baja California Sur, Mexico (fig. 1). The species of macroalgae collected included the rhodophytes Opuntiella californica (15-004), Laurencia gardnerii (07-002), Laurencia lajolla (13-003), and Gracilaria vermiculophylla (14-023); the phaeophytes Sargassum horridum (15-007), Sargassum Sinicola (15-002), Colpomenia tuberculata (06-030) and Padina sp. (15-001); and the chlorophytes Ulva lactuca (14-014) and Codium fragile (10-001). All species were identified by Dr. Rafael Riosmena and Dr. Juan Manuel López Vivas from the Phycology laboratory of the Autonomous University of Baja California Sur, Mexico.

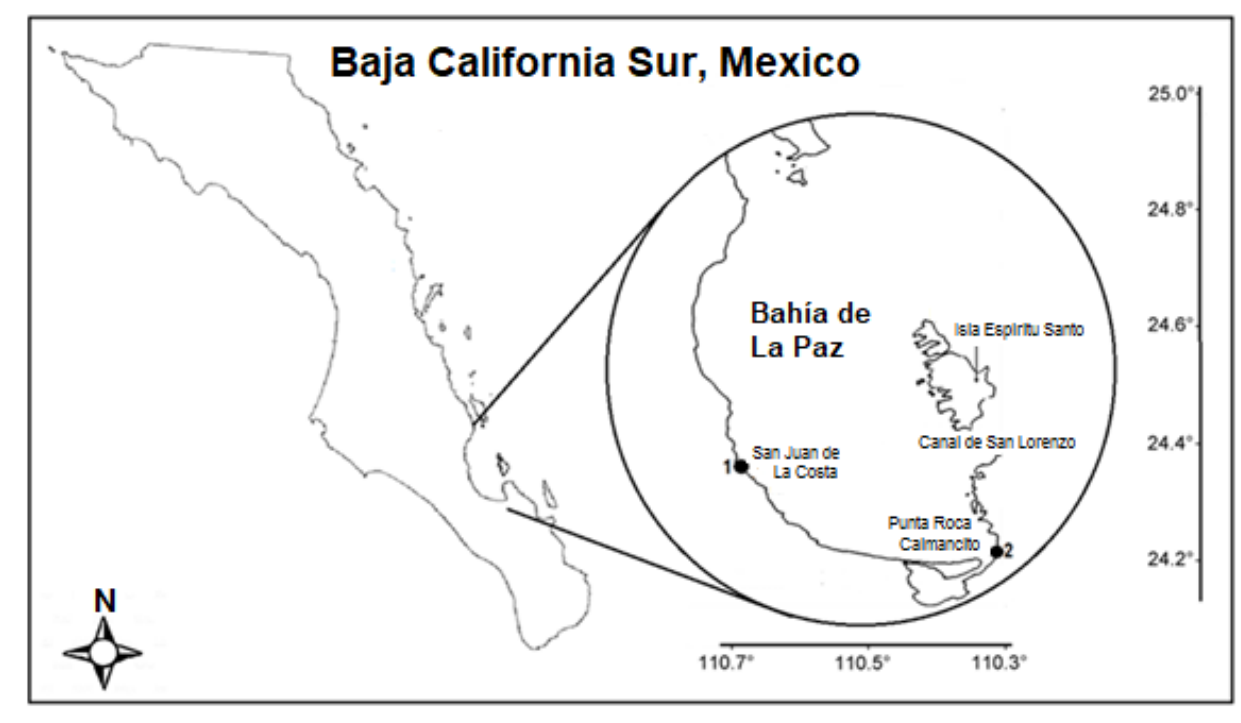

Fig. 1: Algae collection sites in Bahía de La Paz, at the south of Baja California peninsula: 1) San Juan de la Costa and 2) Punta Roca Caimancito

All macroalgae materials were washed with fresh water to remove foreign matter and subsequently sun-dried, ground, and stored at $-20^{\circ} \mathrm{C}$. A total of $300 \mathrm{~g}$ of each species was exhaustively macerated with $100 \%$ distilled dichloromethane $\left(\mathrm{CH}_{2} \mathrm{Cl}_{2}\right)$. Subsequently, a second maceration with $100 \%$ ethanol (EtOH) was performed. Both extractions with $\mathrm{CH}_{2} \mathrm{Cl}_{2}$ and EtOH were performed for nine days, and the solvents were replaced every third day. The resulting solution was dried at $40{ }^{\circ} \mathrm{C}$ in a rotary evaporator under reduced pressure to obtain two crude organic extracts of each sample. To obtain the aqueous extract, $100 \mathrm{~g}$ of dry material that had been previously extracted with the organic solvents was used. The extracts were placed in distilled water and continuously stirred at room temperature $\left(25^{\circ} \mathrm{C}\right)$ for $4 \mathrm{~h}$. The temperature was increased to $80^{\circ} \mathrm{C}$ and stirred for an additional 2 h. The aqueous extracts were centrifuged at $3000 \mathrm{rpm}$ until clarified solutions were obtained. Each extract was precipitated with the addition of 3 volumes of ethanol. Finally, the precipitate was recovered by centrifugation and dried in an electric oven at $50^{\circ} \mathrm{C}$. All the extracts were stored at $-20^{\circ} \mathrm{C}$ until further use.

\section{Anti-inflammatory activity}

Three indirect in vitro methods and one in vivo method were used to determine anti-inflammatory activity. In vitro methods consisted of 1) the membrane protection of red blood cells (HRBCs) against hemolysis induced by hypotonicity, 2) the inhibition of heat-induced protein denaturation (IDP), and 3) the inhibition of the myeloperoxidase (MPO) enzyme. The in vivo method consisted of the topical administration of 12-0-Tetradecanoylphorbol-13-acetate (TPA), which caused acute edema with leukocyte infiltration.

\section{Human red blood cell (HRBC) method}

This assay was conducted following the method proposed by Chippada [17]. To prepare the HRBC suspension, blood was obtained by venipuncture from an apparently healthy donor, a fresh blood sample was mixed with an equal volume of sterile Alsever solution $(2 \%$ dextrose, $0.8 \%$ sodium citrate, $0.05 \%$ citric acid, and $0.42 \%$ sodium chloride in water). The mixture was centrifuged at $3000 \mathrm{rpm}$ for $10 \mathrm{~min}$, and the cell pellet was recovered by decantation and washed three times with an isotonic solution $(0.85 \%, \mathrm{pH} 7.2)$. A suspension $(10 \% \mathrm{v} / \mathrm{v})$ with an isotonic solution was prepared with the cell pellet.
The assay mixture contained $1 \mathrm{ml}$ of phosphate buffer $(\mathrm{pH} 7.4,0.15$ M), $2 \mathrm{ml}$ of hypotonic saline solution $(0.36 \%), 0.5 \mathrm{ml}$ of the HRBC suspension $(10 \% \mathrm{v} / \mathrm{v})$, and $0.5 \mathrm{ml}$ of algal extract $(10 \mu \mathrm{g} / \mathrm{ml})$. All extracts were incubated at $37{ }^{\circ} \mathrm{C}$ for $30 \mathrm{~min}$ and centrifuged. Diclofenac sodium $(10 \mu \mathrm{g} / \mathrm{ml})$ was used as a control and distilled water was used as a blank. The hemoglobin content in the supernatant solution was estimated by reading the sample at 560 $\mathrm{nm}$ in a Spectronic 20D spectrophotometer (Milton Roy, Rochester, USA).

The hemolysis percentage of the HRBC membrane was calculated with Eq. (1):

$$
\text { Hemolysis }(\%)=\left(\frac{O D_{\text {sample }}}{O D_{\text {control }}}\right) 100,
$$

Where $O D_{\text {sample }}$ and $O D_{\text {control }}$ are the optical density of the sample and control, respectively.

The HRBC membrane protection percentage was calculated with Eq. (2):

Protection $(\%)=100-\%$ hemolysis Eq. (2)

\section{Inhibition of the protein denaturation method}

The test solution $(1 \mathrm{ml})$ consisted of $0.90 \mathrm{ml}$ of egg albumin $(1 \% \mathrm{w} / \mathrm{v}$ aqueous solution) and $0.1 \mathrm{ml}$ of the test extract $(10 \mu \mathrm{g} / \mathrm{ml})$. The negative control $(1 \mathrm{ml})$ consisted of $0.90 \mathrm{ml}$ of egg albumin $(1 \% \mathrm{w} / \mathrm{v}$ aqueous solution) and $0.1 \mathrm{ml}$ of distilled water. This negative control represented $100 \%$ protein denaturation. The positive control $(1 \mathrm{ml})$ was prepared with $0.90 \mathrm{ml}$ of distilled water and $0.1 \mathrm{ml}$ of diclofenac sodium at a concentration of $10 \mu \mathrm{g} / \mathrm{ml}$. All solutions were adjusted to a $\mathrm{pH}$ of 6.3. Samples were incubated at $37^{\circ} \mathrm{C}$ and after $20 \mathrm{~min}$, the temperature was increased to $57^{\circ} \mathrm{C}$ for $30 \mathrm{~min}$. After cooling, $2.5 \mathrm{ml}$ of phosphate buffer was added. The samples were read at $416 \mathrm{~nm}$ in a Spectronic 20D spectrophotometer (Milton Roy). The protein denaturation inhibition percentage was calculated according to Eq. (3) [18].

Inhibition $(\%)=\left[100-\frac{\left(\mathrm{OD}_{\text {extract }}-\mathrm{OD}_{\text {control }}\right.}{\mathrm{OD}_{\text {control }}}\right] 100 \%$

Where $O D_{\text {extract }}$ and $O D_{\text {control }}$ are the optical density of the extract and control, respectively. 
TPA-induced mouse ear edema and the evaluation of antiinflammatory effects

The assay was carried out according to the methods described by Young [19]. Male CD-1 strain mice with weights between 25-30 g were used for the bioassay ( $n=3$ mice per extract). The mice were supplied by the bioterium of the Instituto de Fisiología Celular of the Universidad Nacional Autónoma de México (UNAM) and maintained with free access to food and water under standard conditions $\left(22 \pm 4{ }^{\circ} \mathrm{C} ; 12 / 12 \mathrm{~h}\right.$ light/dark cycle) according to the regulations established by the official Mexican standard NOM-062-Z00-1999 and international guidelines. Experimental procedures followed the protocol approved by the internal Animal Ethics Committee of UNAM (CICUAL-IQ-004-17).

On both sides of the right ear, $10 \mu \mathrm{l}$ of ethanolic solution of the TPA $(2.5 \mu \mathrm{g} / \mathrm{ml})$ irritant was topically applied. The extracts $(1 \mathrm{mg})$ or the reference drug (indomethacin) were diluted in $20 \mu \mathrm{l}$ of ethanol or ethanol/acetone (1:1), respectively, and administered after TPA application on both sides of the right ear. The left ear was used as a control and only ethanol and the sample solvent [ethanol or ethanol/acetone (1:1)] were applied. After $4 \mathrm{~h}$, the animals were euthanized in a $\mathrm{CO}_{2}$ chamber. After which, a sample of each ear was obtained with a 7-mm diameter punch. The amount of swelling was calculated based on the weight difference between the right and left ear samples with Eq. (4):

$$
\Delta \text { weight }(\mathrm{mg})=\left[\text { Weight }_{\text {Ear R }}-\text { Weight }_{\text {Ear L }}\right] \text {..... }
$$

Where Weight Ear $R_{\text {is }}$ the weight of the treated ear, and Weight Ear $L_{\text {is }}$ the weight of the non-treated ear.

Anti-inflammatory activity was expressed as the edema inhibition percent with Eq. (5)

$$
\text { edema inhibition }(\%)=\left(\frac{\Delta \text { Weight }_{\mathrm{A}}-\Delta \text { Weight }_{\mathrm{B}}}{\Delta \text { Weight }_{\mathrm{A}}}\right) 100
$$

Where $\mathrm{A}$ is the edema induced by TPA alone, and B is the edema induced by TPA plus sample.

\section{Ethics approval}

The mice in this study were maintained according to the regulations established in the official Mexican standard (NOM-062-ZOO-1999) and international guidelines. Experimental procedures followed the protocol approved by the internal Animal Ethics Committee of the Universidad Nacional Autónoma de México (UNAM; CICUAL-IQ-004-17).

\section{Myeloperoxidase (MPO) assay}

An evaluation of the activity of the extracts and fractions on the MPO enzyme was carried out following the methods described by Bradley and Suzuki $[20,21]$. The mouse-ear biopsies were crushed with the aid of a metal homogenizer for $30 \mathrm{~s}$ in $1 \mathrm{ml}$ of phosphate-buffered saline (PBS) with $0.5 \%$ hexadecyltrimethylammonium bromide (HTAB). Subsequently, the samples were frozen and thawed 3 times to induce tissue rupture. At the end of this step, the samples were centrifuged for $5 \mathrm{~min}$ at $12,000 \mathrm{rpm}$ and $4{ }^{\circ} \mathrm{C}$. The supernatant $(10$ $\mu \mathrm{l})$ was taken in quadruplicate and placed in a 96-well plate. A total of $10 \mu \mathrm{l}$ of $0.5 \%$ HTAB was used as the target. In each well, $180 \mu \mathrm{l}$ of PBS was added without HTAB, followed by $20 \mu \mathrm{l}$ of $0.017 \% \mathrm{H}_{2} \mathrm{O}_{2}$. The reaction was initiated by adding $20 \mu \mathrm{l}$ of $3,3^{\prime}, 5,5^{\prime}$ tetramethylbenzidine (TMB) $18.4 \mu \mathrm{M}$ and incubated for $5 \mathrm{~min}$ at 37 ${ }^{\circ} \mathrm{C}$ with gentle shaking. After this time, the reaction was stopped by adding $20 \mu \mathrm{l}$ of $2 \mathrm{M} \mathrm{H}_{2} \mathrm{O}_{2}$. Enzymatic activity was determined by the difference in optical density at $450 \mathrm{~nm}$ with Eq. (6).

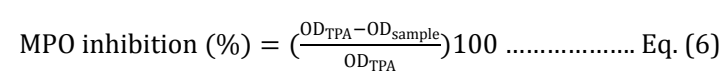

Where, $O D_{T P A}$ is the optical density of the biopsy with TPA alone, and $O D_{\text {sample }}$ is the optical density of biopsy with TPA plus sample.

\section{Phytochemical analysis}

The compound profile of each crude extract was evaluated by thinlayer chromatography (TLC) on normal phase glass silica gel plates. An eluent system of $\mathrm{CH}_{2} \mathrm{Cl}_{2}: \mathrm{MeOH}$ (9:1) was employed. The plates were completely dried to remove excess solvent. Subsequently, they were sprayed with developers (table 1) to identify the presence of major compounds [22].

\section{Statistical analysis}

Multiple comparisons were performed with one-way analyses of variance (ANOVA) followed by Dunnett post-hoc tests. Data are presented as the mean \pm standard error of the mean (SEM). $P$-values $\leq 0.05$ were considered significant.

\section{RESULTS}

Dichloromethane $\left(\mathrm{CH}_{2} \mathrm{Cl}_{2}\right)$, ethanol $(\mathrm{EtOH})$, and aqueous $\left(\mathrm{H}_{2} \mathrm{O}\right)$ extracts were obtained from each species of macroalgae. A total of 30 extracts were evaluated with in vitro and in vivo assays to determine their activity.

\section{In vitro anti-inflammatory activity (HRBC method)}

Human red blood cell membrane stabilization was utilized to determinate anti-inflammatory activity. Most of the aqueous extracts showed a high percentage of red cell membrane protection $(>90 \%)$, except for the Padina sp., L. gardnerii, and U. lactuca extracts, which had low activity $(<65 \%$; table 1$)$. The dichloromethane extracts from the red algae $O$. californica, L. lajolla, and G. vermiculophylla showed the highest protection percentages $(>95 \%)$ and were similar to that of diclofenac sodium (98.5\%), which was used as a positive control. The membrane protection percentages of the green and brown algae extracts generally did not exceed $30 \%$. In general, the ethanol extracts were the least active among all extracts, and only two red algae ( $L$. lajolla and G. vermiculophylla) and the brown algae of the Sargassum genus had activity percentages above $70 \%$. The ethanol extracts of $O$. californica and $C$. fragile did not present activity and allowed for complete membrane lysis (table 1).

\section{Inhibition of protein denaturation}

The aqueous extract of $G$. vermiculophylla presented the highest inhibitory effect $(85 \%)$ on protein denaturation at a concentration of $10 \mu \mathrm{g} / \mathrm{ml}$ compared to those of the other extracts (table 1). At the same concentration with diclofenac sodium, 96\% inhibition was obtained. The other aqueous extracts with activity were from Padina sp., C. tuberculata, and L. gardnerii, with activities of 31,17 , and $10 \%$, respectively. The dichloromethane extracts of the red algae $G$. vermiculophylla, L. gardnerii, and 0 . californica presented 54,49 , and $30 \%$ protection of the protein structures, respectively. The rest of the algae extracts did not inhibit protein denaturation. In general, the ethanol extracts conferred low protein structure protection, with $L$. gardneri, $C$. fragile, and Padina sp. showing the highest denaturation inhibition percentages of 47,30 , and $28 \%$, respectively.

TPA-induced edema mouse ear assay and anti-inflammatory effects

The topical application of TPA induced an increase in ear weight (15.8 $\mathrm{mg}$ ) due to edema during the inflammation process. The dichloromethane extracts resulted in higher reductions of inflammation with edema inhibition percentages between 41 and $65.7 \%$ (fig. 2). The rhodophyte extracts presented the greatest edema inhibition (G. vermiculophylla, 65.7\%; O. californica, 64.2\%). Other extracts with good activity were those from the brown algae $C$. tuberculata and the green algae $C$. fragile with $61.5 \%$ and $61.2 \%$ edema reduction, respectively (fig. $2 \mathrm{~A}$ ). The anti-inflammatory activity of the ethanol extracts was low $(<35 \%)$. The extracts from L. gardneri, C. fragile, L. lajolla, and Padina sp. reached edema inhibition values between 19 and $22 \%$ (fig. 2B). In the case of the aqueous extracts, only four of these could be evaluated since total dissolution was not always achieved. The aqueous extracts (fig. 3C) showed a minor effect on the reduction of mouse ear edema; only the $C$. tuberculata extract showed slightly more than $10 \%$ inhibition. Indomethacin was used as a positive control and was able to inhibit edema by $82.3 \%$.

\section{Myeloperoxidase (MPO) activity}

The effects of the macroalgae extracts and indomethacin on MPO levels in the TPA-induced mouse ear edema are shown in fig. 3. In the TPA treatment group, MPO activity was $100 \%$, while indomethacin (positive control) reduced MPO activity by $95 \%$. The extracts with the greatest effects on MPO activity in the ear tissues were the dichloromethane extracts of G. vermiculophylla and $C$. tuberculata, which caused a $70 \%$ reduction in MPO activity, followed by the $O$. californica extract, which caused a reduction in MPO 
activity of $56 \%$ (fig. 3A). The ethanol and aqueous extracts showed lower activity compared to those of the other extracts, and most active extracts reduced MPO activity by about 50\%. The ethanol extracts of $U$. lactuca reduced MPO activity by $56 \%$ (fig. 3B), and the aqueous extracts of $C$. tuberculata, $G$. vermiculophylla, and $C$. fragile inhibited MPO activity by $52-55 \%$ (fig. 3B, C).

Table 1: Percentage of in vitro anti-inflammatory activity determined by human red blood cell (HRBC) and heat-induced protein denaturation (IDP) of the dichloromethane $\left(\mathrm{CH}_{2} \mathrm{Cl}_{2}\right)$, ethanol (EtOH) and aqueous $\left(\mathrm{H}_{2} \mathrm{O}\right)$ extracts of the macroalgae collected from Bahía de La Paz, B.C.S., Mexico

\begin{tabular}{|c|c|c|c|}
\hline & Extract $(10 \mu \mathrm{g} / \mathrm{ml})$ & HRBC (\%) & IDP (\%) \\
\hline \multicolumn{4}{|l|}{ Rhodophytes } \\
\hline \multirow[t]{3}{*}{ Opuntiella californica } & $\mathrm{CH}_{2} \mathrm{Cl}_{2}$ & $95.2 \pm 0.00$ & $30 \pm 2.0$ \\
\hline & EtOH & NA & NA \\
\hline & $\mathrm{H}_{2} \mathrm{O}$ & $98.2 \pm 0.00$ & NA \\
\hline \multirow[t]{3}{*}{ Laurencia gardnerii } & $\mathrm{CH}_{2} \mathrm{Cl}_{2}$ & $15.6 \pm 0.19$ & $49 \pm 2.8$ \\
\hline & EtOH & $72.1 \pm 0.01$ & $9 \pm 0.5$ \\
\hline & $\mathrm{H}_{2} \mathrm{O}$ & $63.2 \pm 0.05$ & $10 \pm 0.9$ \\
\hline \multirow[t]{3}{*}{ Laurencia lajolla } & $\mathrm{CH}_{2} \mathrm{Cl}_{2}$ & $96.6 \pm 0.01$ & NA \\
\hline & EtOH & $20.4 \pm 0.00$ & $47 \pm 2.5$ \\
\hline & $\mathrm{H}_{2} \mathrm{O}$ & $93.0 \pm 0.05$ & NA \\
\hline \multirow{3}{*}{ Gracilaria vermiculophylla } & $\mathrm{CH}_{2} \mathrm{Cl}_{2}$ & $95.0 \pm 0.00$ & $54 \pm 2.5$ \\
\hline & EtOH & $77.4 \pm 0.01$ & $28 \pm 2.0$ \\
\hline & $\mathrm{H}_{2} \mathrm{O}$ & $93.5 \pm 0.05$ & $85 \pm 3.5$ \\
\hline \multicolumn{4}{|l|}{ Phaeophytes } \\
\hline \multirow[t]{3}{*}{ Sargassum horridum } & $\mathrm{CH}_{2} \mathrm{Cl}_{2}$ & NA & NA \\
\hline & EtOH & $70.0 \pm 0.01$ & $27 \pm 1.5$ \\
\hline & $\mathrm{H}_{2} \mathrm{O}$ & $92.8 \pm 0.03$ & NA \\
\hline \multirow[t]{3}{*}{ Sargassum sinicola } & $\mathrm{CH}_{2} \mathrm{Cl}_{2}$ & $29.2 \pm 0.08$ & NA \\
\hline & EtOH & $77.7 \pm 0.01$ & NA \\
\hline & $\mathrm{H}_{2} \mathrm{O}$ & $96.9 \pm 0.05$ & NA \\
\hline \multirow[t]{3}{*}{ Colpomenia tuberculata } & $\mathrm{CH}_{2} \mathrm{Cl}_{2}$ & NA & NA \\
\hline & EtOH & $73.5 \pm 0.02$ & NA \\
\hline & $\mathrm{H}_{2} \mathrm{O}$ & $92.7 \pm 0.04$ & NA \\
\hline \multirow{3}{*}{ Padina sp. } & $\mathrm{CH}_{2} \mathrm{Cl}_{2}$ & $10.7 \pm 0.05$ & NA \\
\hline & EtOH & $21.9 \pm 0.20$ & $28 \pm 1.9$ \\
\hline & $\mathrm{H}_{2} \mathrm{O}$ & $27.4 \pm 0.07$ & $31 \pm 1.8$ \\
\hline \multicolumn{4}{|l|}{ Chlorophytes } \\
\hline \multirow[t]{3}{*}{ Ulva lactuca } & $\mathrm{CH}_{2} \mathrm{Cl}_{2}$ & NA & $15 \pm 0.5$ \\
\hline & EtOH & $20.4 \pm 0.01$ & $1 \pm 0.0$ \\
\hline & $\mathrm{H}_{2} \mathrm{O}$ & $56.8 \pm 0.01$ & NA \\
\hline \multirow{3}{*}{ Codium fragile } & $\mathrm{CH}_{2} \mathrm{Cl}_{2}$ & $21.1 \pm 0.07$ & NA \\
\hline & $\mathrm{EtOH}$ & NA & $30 \pm 1.9$ \\
\hline & $\mathrm{H}_{2} \mathrm{O}$ & $94.1 \pm 0.04$ & NA \\
\hline \multicolumn{4}{|l|}{ Control } \\
\hline Diclofenac sodium $(10 \mu \mathrm{g} / \mathrm{ml})$ & & $98.6 \pm 0.00$ & $96 \pm 4.0$ \\
\hline
\end{tabular}

Abbreviations: HRBC, human red blood cell; IDP, inhibition of protein denaturation; NA, no activity. Data are expressed as mean \pm SEM; $\mathrm{n}=3$.

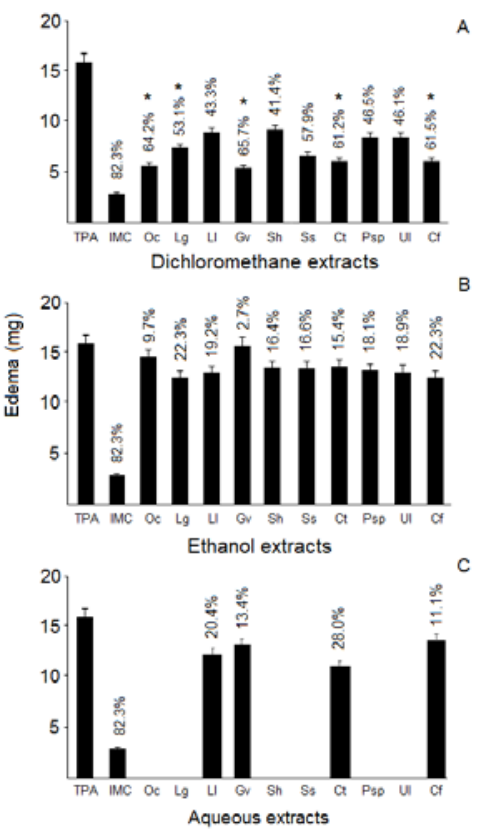

Fig. 2: Topical anti-inflammatory activity of the macroalgae extracts (1 mg/ear). A) Dichloromethane $\left(\mathrm{CH}_{2} \mathrm{Cl}_{2}\right)$, B) ethanol (EtOH), and C) aqueous $\left(\mathrm{H}_{2} \mathrm{O}\right)$ extracts. Data are expressed as the mean $\pm \mathrm{SEM}$; $n$ = 3 for ear edema. ${ }^{*} \mathbf{P}<0.05$; compared-to the control. The edema inhibition percentage is located above each bar. Abbreviations: TPA, 12-tetradecanoylphorbol 13-acetate; IMC, Indomethacin; Oc, Opuntiella californica; Lg, Laurencia gardnerii; Ll, Laurencia lajolla; Gv, Gracilaria vermiculophylla; Sh, Sargassum horridum; Ss,
Sargassum sinicola; Ct, Colpomenia tuberculate; Psp, Padina sp.; Ul, Ulva lactuca; and Cf, Codium fragile
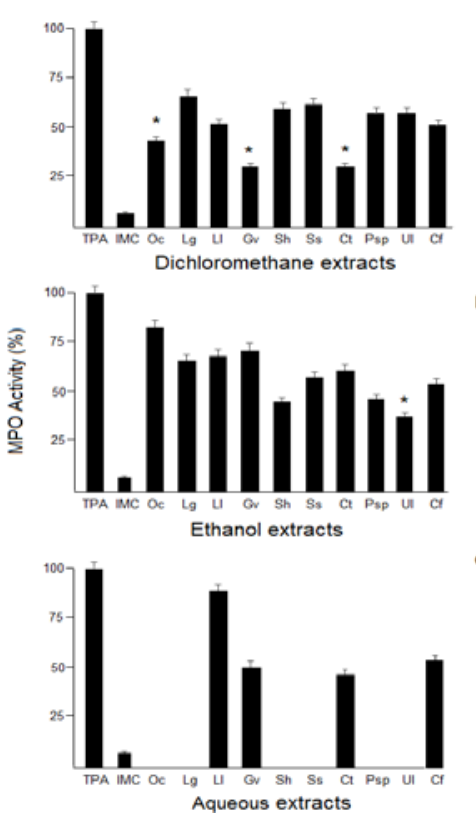

Fig. 3: Comparative effect of the macroalgae extracts and indomethacin on myeloperoxidase (MPO) levels in TPA-inducted ear mouse edema. A) Dichloromethane $\left(\mathrm{CH}_{2} \mathrm{Cl}_{2}\right)$, B) ethanol (EtOH), and $\mathrm{C}$ ) aqueous $\left(\mathrm{H}_{2} \mathrm{O}\right)$ extracts. Data are expressed as mean $\pm S E M ; n=4 * P<0.05$ compared to the control. Abbreviations: TPA, 12-tetradecanoylphorbol 13-acetate; IMC, Indomethacin; Oc, 
Opuntiella californica; Lg, Laurencia gardnerii; Ll, Laurencia lajolla; Gv, Gracilaria vermiculophylla; Sh, Sargassum horridum; Ss, Sargassum sinicola; $\mathrm{Ct}$, Colpomenia tuberculata; Psp, Padina sp.; Ul, Ulva lactuca; and Cf, Codium fragile

\section{Phytochemical analysis}

Considering the anti-inflammatory activity obtained in the different in vitro and in vivo assays, the phytochemical characteristics of the extracts with the highest potential are summarized in table 2 . The principal constituents of the macroalgae extracts were flavonoids, terpene-type compounds, and alkaloids. Flavonoids were present in almost all extracts except for those of $C$. fragile. Coumarins and phenols were absent in most extracts. Coumarins were only detected in $G$. vermiculophylla and C. tuberculata extracts, whereas phenols were only detected in L. gardneri and Padina sp. extracts.

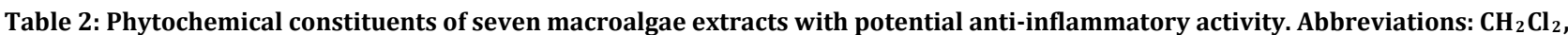
Dichloromethane; EtOH, Ethanol; Flav, Flavonoids; Ter, Terpenoids; Alk, Alkaloids; Sap, Saponins; Coum, Coumarins

\begin{tabular}{|c|c|c|c|c|c|c|c|}
\hline \multirow[t]{2}{*}{ Extract } & & \multicolumn{6}{|c|}{ Phytochemical profile } \\
\hline & & Flav & Terp & Alk & Sap & Coum & Phenols \\
\hline \multicolumn{8}{|l|}{ Rhodophytes } \\
\hline Gracilaria vermiculophylla & $\mathrm{CH}_{2} \mathrm{Cl}_{2}$ & + & + & - & - & + & - \\
\hline Laurencia gardnerii & $\mathrm{CH}_{2} \mathrm{Cl}_{2}$ & + & + & - & - & - & + \\
\hline Opuntiella califórnica & $\mathrm{CH}_{2} \mathrm{Cl}_{2}$ & + & + & + & - & - & - \\
\hline Laurencia lajolla & EtOH & + & - & + & + & - & - \\
\hline \multicolumn{8}{|l|}{ Phaeophytes } \\
\hline Colpomenia tuberculata & $\mathrm{CH}_{2} \mathrm{Cl}_{2}$ & + & - & + & - & + & - \\
\hline $\begin{array}{l}\text { Padina sp. } \\
\text { Chlorophytes }\end{array}$ & $\mathrm{EtOH}$ & + & - & - & + & - & + \\
\hline Codium fragile & EtOH & - & + & + & + & - & - \\
\hline
\end{tabular}

\section{DISCUSSION}

In the search for new marine resources with anti-inflammatory properties, bioprospection is necessary, especially in environments with high biodiversity that have not been previously evaluated. Bioprospection studies can provide new resources that may serve as the foundations for novel solutions to health problems [23]. As such, the anti-inflammatory potential of the extracts from ten macroalgae from Bahía de La Paz, Mexico, was evaluated using in vitro and in vivo assays, and the profiles of the chemical constituents in the crude extracts were identified.

The HRCB method is an in vitro assay of the anti-inflammatory activity of a drug. The erythrocyte membrane is analogous to the lysosomal membrane, this implies that if an extract can stabilize the erythrocyte membrane against the effects of hypotonicity, it will also be able to stabilize the lysosomal membrane. This stabilization prevents the release of lysosomal constituents of activated neutrophils, which cause damage and thus limit the inflammatory response [24-26]. In this sense, the dichloromethane and ethanol extracts of the red algae $O$. californica, L. lajolla, and $G$. vermiculophylla showed anti-inflammatory properties and exhibited $>95 \%$ membrane protection, suggesting that they possess antiinflammatory properties similar to the ones obtained from diclofenac sodium (positive control). Although there are no reports of erythrocyte membrane stabilization due to hypotonicity, the results obtained with organic extracts from rhodophytes are comparable to those reported for higher plants. The methanol extract of Anisomeles malabarica Linn [18] has been found to have the maximum membrane stabilization effect $(98.3 \%)$ but at a higher concentration $(2 \mathrm{mg} / \mathrm{ml})$ than the one used in this study $(10 \mu \mathrm{g} / \mathrm{ml})$. In other studies, the membrane stabilization percentages were lower than the values observed in this study. For example, a membrane stabilization percentage of $57.4 \%$ was obtained with a methanolic extract from Michelia champaca at concentrations between 100 and $300 \mu \mathrm{g} / \mathrm{ml}$, while $63.8 \%$ membrane stabilization was obtained with an extract based on plant mixtures [27, 28]. With regard to the extracts from brown algae, the activity of the aqueous extracts of $S$. horridum, $S$. sinicola, and C. tuberculata were very promising since they showed high stabilization effects (>90\%). It has been determined that aqueous extracts of brown algae contain polyanionic polysaccharides, such as fucoidan and alginates, which could be related with this activity [29]. The ethanol extracts of $S$. horridum, S. sinicola, and C. tuberculate showed minor stabilization membrane effects compared to those of their aqueous extracts (70$73 \%)$.

However, these extracts may be very promising, especially when compared with the membrane stabilization results obtained with the methanolic extract of Sargassum wigthii, which showed values between 52 and $54 \%$ at concentrations up to $50 \mu \mathrm{g} / \mathrm{ml}$ [30].

Another cause of inflammation is the denaturation of tissue proteins, which can result in the production of autoantigens in certain arthritic diseases $[31,32]$. The results of this study showed that the aqueous extract of $G$. vermiculophylla $(10 \mu \mathrm{g} / \mathrm{ml})$ had the highest protein denaturation inhibitory ability $(85 \%)$ compared with that of diclofenac sodium (96\%). This result indicates that this extract could have anti-inflammatory and anti-rheumatoid properties [33]. Similar effects were obtained for a polyherbal extract with $72.8 \%$ inhibition and the ethanolic extract of Oryza sativa, a rice species of Indian origin, which had an inhibitory effect of $84.2 \%$ at a concentration of $500 \mu \mathrm{g} / \mathrm{ml}[28,34]$.

The TPA-induced ear edema model is commonly used in the search for compounds with anti-inflammatory activity and to evaluate the activity of mediators, such as leukotrienes, prostaglandins, and lysosomal enzymes, and leukocyte migration-degranulation through the release of various enzymes like MPO. The topical application of TPA induced inflammation with associated edema formation and increased MPO activity [35-37]. With regard to antiedematous activity, the dichloromethane extracts exhibited the greatest effects with respect to the edema inhibition percentage, specifically the extracts from the red algae $G$. vermiculophylla (65.7\%), O. californica (64.2\%), and L. gardnerii (53.1\%). A similar study with G. verrucosa found promising activity, with $79 \%$ ear edema inhibition [38]. In the phytochemical analysis, it was observed that the main compounds of the red algae used in this study were flavonoids, coumarins, and phenols. In addition to histamine release inhibition, cell migration inhibition, free radical sequestration, and the vascular protective effect, it is known that many flavonoids and phenols act synergistically to enhance anti-inflammatory effects, and a possible mechanism of action may be the inhibitory activity they exert on prostaglandin synthetase $[39,40]$.

With respect to the brown algae in this study, the dichloromethane extracts of $C$. tuberculata $(61.2 \%)$ and S. sinicola (57.9\%) were the most active. Khan [39] reported similar results and demonstrated that the methanol extracts of Colpomenia bullosa and Colpomenia sinuosa inhibited ear mouse edema by 52 and $72 \%$, respectively, at a concentration similar to that used in the present study. In the phytochemical analysis of brown algae, mainly flavonoid compounds were identified. Flavonoids are widely distributed among terrestrial (e. g., upper plants) and marine (e. g., macroalgae, sponges, and tunicates) organisms $[38,41]$. This group of compounds has been widely studied and diverse pharmacological properties have been attributed to this group, such as antiviral, antibacterial, neuroprotective, and anti-inflammatory activities [42-45]. 
Antioxidant effects, metal chelation, enzymatic inhibition, and gene regulation are among the mechanisms that have been proposed to explain the biological activities of these compounds [46]. Specifically, the anti-inflammatory activity of flavonoids has been found to result from the combination of iron-chelating properties and free radical scavengers in addition to the inhibition of oxidases, such as lipoxygenase, cyclooxygenase, myeloperoxidase, NADPH oxidase, and xanthine oxidase [47]. Other mechanisms could also include the inhibition of enzymes involved in oxidative processes, such as phospholipase A2, and the stimulation of other enzymes with antioxidant properties, such as catalase and superoxide dismutase [48]. Other compounds like the polysaccharides obtained from Lobophora variegata have been found to reduce edema induced in rat legs by up to $44 \%[30,38]$.

The extracts from the green algae group had low anti-inflammatory activity, and only the aqueous extract from $C$. fragile managed to protect erythrocyte membranes against induced hemolysis. In the in vivo assay, the dichloromethane extract of $C$. fragile inhibited ear edema up to $61 \%$ and the activity of the MPO enzyme by $50 \%$. The activity of the $C$. fragile dichloromethane extract was higher than that of a methanol extract from $C$. fragile collected from the Korean coast, which barely exceeded $30 \%$ activity [38]. In other green algae, better results have been observed than those of our study. For example, a methanol extract of $U$. lactuca achieved an edema reduction of up to $80 \%$ at a concentration of $500 \mathrm{mg} / \mathrm{kg}$ [49].

The red algae group is considered to be the most important source of biologically active compounds when compared to the brown and green algae groups [4]. The results of the present study indicated that the most active extracts were the dichloromethane extracts of $G$. vermiculophylla and 0 . californica. These extracts showed membrane protective capacity values that reached $\sim 90 \%$. In the in vivo assay, these extracts exhibited an evident reduction in edema and MPO activity. The phytochemical analysis indicated that alkaloid-type compounds, coumarins, flavonoids, and phenols were present in the extracts. Similar results were observed with dichloromethane extracts from Cryptostegia grandiflora, and the authors suggested that structurally diverse compounds with different molecular mechanisms that could enhance anti-inflammatory properties were present in the extracts [37]. Secondary metabolites of different chemical natures and anti-inflammatory activity have been identified with various experimental models and have been isolated from rhodophytes, notably amino acids, peptides, proteins, steroids, terpenes, lipids, and phenols [50-54].

Taking into consideration the results of the in vitro and in vivo assays, the two species that presented the greatest potential antiinflammatory activity were $G$. vermiculophylla and $O$. californica. Gracilaria vermiculophylla is known to be capable of producing compounds with anti-inflammatory activity $[55,56]$. However, this is the first study to report the anti-inflammatory activity of extracts from the brown macroalgae 0 . californica, the results of which are very promising. This group of brown macroalgae (Phaeophyceae) are rich in polyphenols and phlorotannins, and some are used in medicine as their anti-inflammatory activity $[57,58]$.

In this study, the compounds responsible for anti-inflammatory activity were not isolated, but the qualitative phytochemical was described, although the presence of a certain type of metabolite depends on the solvent used in the extraction and the properties of the species, phytochemical analyzes reveal valuable information [59]. Previous studies have reported that seaweeds carry out the biosynthesis of alkaloids, phenols, and flavonoids with similar chemical structures to those of anti-inflammatory drugs. Such is the case with caulerpine, which is a bisindole alkaloid that contains two indole groups (benzylpirroles derived from tryptophan) that are linked by a cyclic 8-carbon ring with two carboxyl groups, which presents anti-inflammatory activity. Caulerpine has been isolated from several species of green and red algae and is structurally similar to indomethacin (indole alkaloid nucleus), which is one of the most commonly used drugs to treat inflammation $[60,61]$. Paracetamol is para-aminophenolic and is used as an analgesic and anti-inflammatory compound. Paracetamol is structurally analogous to the amides synthesized by some red algae, such as benzamide and benzenoacetamide [62]. On the other hand, the ability of rhodophytes to synthesize phenolic compounds that show anti- inflammatory activity via FLAT2 inhibition such as the bromophenols isolated from Vidalia obtusaloba (e. g., viadol A and B) has been recognized due to TPA-induced atrial edema [63]. Another commonly used drug to control inflammatory processes is diclofenac sodium, a derivative of phenylacetic acid. Rhodophytes are capable of synthesizing acetic acid-derived compounds, such as indoleacetic acid and indocarboxylic acid, which have chemical structures that are similar to that of diclofenac sodium [64].

\section{CONCLUSION}

The bioprospection of several macroalgae species from Bahía de La Paz, Mexico, permitted the identification of two species that showed promising anti-inflammatory activity. Gracilaria vermiculophylla showed interesting topical anti-inflammatory effects and compound profiles that may contribute to the biological properties of this seaweed. This is the first study to report the anti-inflammatory activity of Opuntiella californica, and the results regarding both cell membrane protection and topical effects are very promising. The compound profile of these seaweeds indicated the presence of flavonoids, alkaloids, and terpene-type compounds. Additional research is needed to identify the compounds responsible for the anti-inflammatory activities observed in this study in order to offer and cultivate alternative phytopharmaceuticals.

\section{ACKNOWLEDGMENT}

EBGL is grateful to CONACyT and BEIFI-IPN for the student grant. CJHG, MMO and CJBS are COFFA and EDI recipients. ANC received a UNAM grant.

They also thank the PhD. Rafael Riosmena' ${ }^{\dagger}$ and Dr. Juan Manuel López Vivas for algae identification at the UABCS.

\section{FUNDING}

This study was supported by Instituto Politécnico Nacional [grant numbers: 20210126, 20210128 and SIP20211740], CONACyT A1-S14968

\section{AUTHORS CONTRIBUTIONS}

Conceptualization: MMO and CJHG; Data curation: MMO, CJHG. EBGL and ANC; Formal analysis: EBGL, CJHG, MMO, ANC; Funding acquisition: MMO and CJHG; Investigation: EBG, CJHG, ANC and MMO; Methodology: EBG, CJHG, ANC, MMO, CJBS; Project administration: MMO and CJHG, Resources: MMO. and CJHG.; Supervision: CJHG. and MMO.; Validation: EBGL, ANC, MMO and CJHG; Writing-original draft: EBGL, MMO and CJ. HG.; Writing-review and editing: CJHG, MMO, CJBS, ANC.

\section{CONFLICTS OF INTERESTS}

The authors declare no conflict of interest. The funders had no role in the design of the study; in the collection, analyses, or interpretation of data; in the writing of the manuscript; or in the decision to publish the results.

\section{REFERENCES}

1. Robbins LS, Cotran SR, Kumar V. Patología estructural y funcional. $8^{\text {th }}$ ed. Espana, Elsevier Sounders; 2010.

2. Adcock IM. Molecular mechanisms of glucocorticoids actions. Pulm Pharmacol Ther 2000;13:115-26.

3. Espinos D, López A, Calvo E. Bases farmacologicas $\mathrm{y}$ tratamiento de la inflamación. In: Monografía XV. Nuevos avances en medicamentos. Eds. Avendano C. Tamargo, Espana: R Acad Nac Farm; 2004. p. 237-86.

4. El Gamal AA. Biological importance of marine algae. Saudi Pharm J 2010;18:1-25.

5. Vidal A, Fallarero A, Silva de Andrade-Wartha ER. Composición química y actividad antioxidante del alga marina roja Bryothamnion triquetrum (S. G: Gmelin) howe. Rev Bras Cienc Farm 2006;42:589-600.

6. Ahn MJ, Yoon KD, Kim CY, Min SY, Kim Y, Kim HJ, et al. Inhibition of HIV-1 reverse transcriptase and HIV-1 integrase and antiviral activity of Korean seaweed extracts. J Appl Phycol 2020;14:325-9.

7. Llanio M, Hernández MD, Mata A, Cabrera B, Valdez O, Díaz C, et al. Poseen algunas algas de las costas cubanas propiedades 
antiinflamatorias, analgésicas y antioxidantes? Serie Oceanologica 2003. p. 45-60.

8. Rinehart KL, Shaw PD, Shield LS, Gloer JB, Harbour GC, Koker MES, et al. Marine natural products as sources of antiviral, antimicrobial, and neiplastic agents. Pure Appl Chem 1981;53:795-817.

9. Pedroche FF, Santies GA. Ficología marina mexicana. Diversidad y Problemática actual. Hidrobiologica 2003;13:23-32.

10. Muñoz Ochoa M, Murillo Álvarez JI, Zermeno Cervantes LA, Martínez-Díaz SF, Rodríguez Riosmena R. Screening of extracts of algae from Baja California Sur, Mexico as reversers of the antibiotic resistance of some pathogenic bacteria. Eur Rev Med Pharmacol Sci 2010;14:739-47.

11. Garcia Davis S, Murillo Alvarez JI, Muñoz Ochoa M, Carranza Torres E, Garza Padron R, Morales Rubio E, et al. Bactericide, antioxidant and cytotoxic activities from marine algae of genus Laurencia collected in Baja California Sur, Mexico. Int J Pharmacol 2018;14:391-6.

12. González Castro AL, Munoz Ochoa M, Hernandez Carmona G, Lopez Vivas JM. Evaluation of seaweed extracts for the control of the Asian citrus psyllid Diaphorina citri. J Appl Phycol 2019;31:3815-21.

13. Sánchez Lozano I, Hernández Guerrero CJ, Munoz Ochoa M, Hellio C. Biomimetic approaches for the development of new antifouling solutions: study of the incorporation of macroalgae and sponge extracts for the development of new environmentally-friendly coatings. Int J Mol Sci 2019;20:4863.

14. Castro Silva ES, Bello M, Rosales Hernández MC, Correa Basurto J, Hernández Rodriguez M, Villalobos Acosta D, et al. Fucosterol from Sargassum horridum as an amyloid-beta (A $31-42)$ aggregation inhibitor: in vitro and in silico studies. J Biomol Struct Dyn 2021;39:1271-83.

15. Castro Silva ES, Bello M, Hernández Rodríguez M, Correa Basurto J, Murillo Álvarez JI, Rosales Hernández MC, et al. In vitro and in silico evaluation of fucosterol from Sargassum horridum as potential human acetylcholinesterase inhibitor. J Biomol Struct Dyn 2019;37:3259-68.

16. Di Filippo Herrera DA, Munoz Ochoa M, Hernández Herrera RM, Hernández Carmona G. Biostimulant activity of individual and blended seaweed extracts on the germination and growth of the mung bean. J Appl Phycol 2019;31:2025-37.

17. Chippada SC, Volluri SS, Bammidi SR, Vangalapati M. In vitro anti-inflammatory activity of methanolic extract of Centella asiatica by HRBC membrane stabilization. Biosci Biotechnol Rasayan J Chem 2011;4:457-60.

18. Lavanya R, Maheshwari SU, Harish G, Bharath Raj J, Kamali S, Hemamalani $\mathrm{D}$, et al. In vitro antioxidant, anti-inflammatory and anti-arthritic activities in the leaves of Coldenia procumbens linn. Res J Pharm Biol Chem Sci 2010;1:745-52.

19. Young JM, Wagner BM, Spires DA. Tachyphylaxis in 12-0tetradecanoylphorbol acetate-and arachidonic acid-induced ear edema. J Invest Dermatol 1983;48-52.

20. Bradley PP, Priebat DA, Christansen RD, Rothstein G. Measurement of cutaneous inflammation: Estimation of neutrophil content with an enzyme marker. J Inv Derm 1982;78:206-9.

21. Suzuki K, Ota H, Sasagawa S, Sakatani T, Fujikura T. Assay method for myeloeroxidase in human polymorphonuclear leukocytes. Ana Biochem 1983;132:345-52.

22. Harborne JD. Phytochemical methods: guide to modern techniques of plant analysis. London: Chapman and Hall; 1998.

23. Montalvao S, Demirel Z, Devi P, Lombardi V, Hongisto V, Perala $\mathrm{M}$, et al. Large-scale bioprospecting of cyanobacteria, microand macroalgae from the Aegean Sea. N Biotechnol 2016;33:399-406.

24. Saleem TK, Azeem AK, Dilip C, Sankar C, Prasanth NV, Duraisami R. Anti-inflammatory activity of the leaf extracts of Gendarussa vulgaris nees. Asian Pac J Trop Biomed 2011;1:147-9.

25. Mounnissamy VM, Kavimani S, Balu V, Drlin QS. Evaluation of anti-inflammatory and membrane stabilizing properties of ethanol extract of Canjera rehedi. Iran J Pharmacol Ther 2007;6:235-7.
26. Rosales C. Neutrophil: a cell with many roles in inflammation or several cell types? Front Physiol 2018;9:113.

27. Ananthi T, Chitra M. Screening of in vitro anti-inflammatory activity of Michelia champaca linn flowers. Asian J Pharm Clin Res 2013;6:71-2.

28. Deattu N, Narayanan N, Suseela L. Evaluation of antiinflammatory and antioxidant activities of polyherbal extract by in vitro methods. Res J Pharm Biol Chem Sci 2012;3:727-32.

29. Muñoz Ochoa M, Murillo Álvarez JI, Rodríguez Montesinos YE, Hernández-Carmona Carmona G, Arvizu Higuera DL, Peralta Cruz J, et al. Anticoagulant screening of marine algae from Mexico, and partial characterization of the active sulfated polysaccharide from Eisenia arborea. CICIMAR Oceanides 2009;4:41-51.

30. Pramitha VS, Kumari NS. Anti-inflammatory, antioxidant, phytochemical and GC_MS analysis of marine brown macroalga, Sargassum wighti. Int J Pharm Chem Biol Sci 2016;6:7-15.

31. Chandra S, Chatterjee P, Dey P, Bhattacharya S. Evaluation of in vitro anti-inflammatory activity of coffee against the denaturation of protein. Asian Pac J Trop Biomed 2012;2 Suppl 1:178-80.

32. Umapathy E, Ndebia EJ, Meeme A, Adam B, Menziwa P, Nkeh Chungag BN, et al. An experimental evaluation of Albuca setosa aqueous extract on membrane stabilization, protein denaturation and white blood cell migration during acute inflammation. J Med Plants Res 2010;4:789-95.

33. Henneh IT, Ameyaw EO, Biney RP, Armah FA, Obese E, Konjah $\mathrm{D}$, et al. Ziziphus abyssinica hydro-ethanolic root bark extract attenuates acute inflammation possibly through membrane stabilization and inhibition of protein denaturation and neutrophil degranulation. West Afr Pharm 2018;29:81-94.

34. Rahman H, Eswaraiah MC, Dutta AM. In vitro anti-inflammatory and anti-arthritic activity of Oryza sativa var. joha rice (an aromatic indigenous rice of Assam). Am Eurasian J Agric Environ Sci 2015;15:115-21.

35. Ospina LF, Calle J, Arteaga L, Pinzon R, Alcaraz MJ, Paya M. Inhibition of acute and chronic inflammatory responses by the hydroxybenzoquinonic derivative rapanone. Planta Med 2001;67:791-5.

36. Castro JP, Ocampo YC, Franco LA. In vivo and in vitro antiinflammatory activity of Cryptostegia grandiflora Roxb. ex R. Br. leaves. Biol Res 2014;47:1-8.

37. Pinto NB, Morais TC, Carvalho KMB, Silva CR, Andrade GM, Brito GAC, et al. Topical anti-inflammatory potential of Physalin E from Physalis angulata on experimental dermatitis in mice. Phytomedicine 2010;17:740-3.

38. Ferrandiz L, Alcaraz M. Anti-inflammatory activity and inhibition of arachidonic acid metabolism by flavonoids. Agents Actions 1991;32:283-8.

39. Khan MNA, Choi JS, Lee MC, Kim E, Nam TJ, Fujii H, et al. Antiinflammatory activities of methanol extracts from various seaweed species. J Env Biol 2008;29:465-69.

40. Shigeoka S, Ishikawa T, Tamoi M. Regulation and function of ascorbate peroxidase isoenzymes. J Exp Bot 2002;53:1305-19.

41. Lopez LMT. Flavonoides. Fitoterapia 2002;21:108-14.

42. Baalen CA, Schutten M, Huisman RC, Boers PHM, Gruters RA, Ostherhaus ADME. Kinetics of antiviral activity by human immunodeficiency virus type 1 -specific cytotoxic $\mathrm{T}$ lymphocytes (CTL) and rapid selection of CTL escape virus in vitro. Virol J 1998;72:6851-7.

43. Ferry DR, Traunecker H, Kerr DJ. Clinical trials of Pglycoprotein reversal in solid tumours. Eur J Cancer 1996;32:1070-81.

44. Honda S, Sasaki Y, Ohsawa K, Imai Y, Nakamura Y, Inoue K, et al. Extracellular ATP or ADP induce chemotaxis of cultured microglia through Gi/o-Coupled P2Y receptors. J Neurosci 2001;21:1975-82.

45. Kim HP, Mani I, Iversen L, Ziboh VA. Effects of naturally occurring flavonoids and bioflavonoids on epidermal cyclooxygenase and lipoxygenase from guinea pigs. Prostaglandins Leukot Essent Fatty Acids 1998;58:17-24.

46. Elejalde, G Estres. Oxidativo, enfermedades y tratamientos antioxidantes. An Med Int 2001;18:326-35. 
47. De Groot H, Rauen U. Tissue injury by reactive oxygen species and the protective effects of flavonoids. Fundam Clin Pharmacol 1998;12:249-55.

48. Perez TG, Martinez SG. Los flavonoides como antioxidantes naturales. Acta Farm Bonaerense 2001;20:297-306.

49. Margret RJ, Kumaresan S, Ravikumar S. A preliminary study on the anti-inflammatory activity of methanol extract of Ulva lactuca in rat. J Environ Biol 2009;30:899-902.

50. Shin ES, Hwang HJ, Kim IH, Nam TJ. A glycoprotein from Porphyra yezoensis produces anti-inflammatory effects in liposaccharide-stimulated macrophages via the TLR4 signaling pathway. Int J Mol Med 2011;28:809-15.

51. Da S, Bitencourt F, Figueiredo JG, Mota MR, Bezerra CC, Silvestre PP, et al. Antinociceptive and anti-inflammatory effects of a mucin-binding agglutinin isolated from the red marine alga Hypnea cervicornis. Naunyn Schmiedebergs Arch Pharmacol 2008;377:139-48.

52. Chatter R, Othman RB, Rabhi S, Kladi M, Tarhouni S, Vagias C, et al. In vivo and in vitro anti-inflammatory activity of neorogioltriol, a new diterpene extracted from the red algae Laurencia glandulifera. Mar Drugs 2011;9:1293-306.

53. Cavalcante Silva LH, da Matta CBB, Araujo MV, Barbosa Filho JM, de Lira DP, de Oliveira Santos BV, et al. Antinociceptive and anti-inflammatory activities of crude methanolic extract of red alga Bryothamnion triquetrum. Mar Drugs 2012;10:1977-92.

54. Lim CS, Jin DQ, Sung JY, Lee JH, Choi HG, Ha I, et al. Antioxidant and anti-inflammatory activities of the methanolic extract of Neorhodomela aculeate in hippocampal and microglial cells. Biol Pharm Bull 2006;29:1212-6.

55. Da Costa E, Melo T, Moreira ASP, Bernardo C, Helguero L, Ferreira I, et al. Valorization of lipids from Gracilaria sp. through lipidomics and decoding of antiproliferative and antiinflammatory activity. Mar Drugs 2017;15:1-17.

56. Chalini K, Johnson M, Adaikalara JG, Vidyarani G, Rmanakrishnan P. Anti-inflammatory activity of aqueous extracts of Gracilaria. Int J Curr Pharm Res 2017;9:17-9.

57. Saxena MK, Singh N, Kumar S, Dobhal MP, Datta S. Review potent pharmaceuthical products from aquatic plants-review. Asian J Pharm Clin Res 2020;14:48-63.

58. Hellwig V, Gasser J. Polyphenols from waste streams of food industry: valorisation of blanch water from marzipan production. Phytochem Rev 2020;22:1-8.

59. Pradeepa M, Kalidas V, Geetha N. Qualitative and quantitative phytocehmical analysis and bactericidal activity of pelargonium graveolens Lher. Int J Appl Pharm 2016;8:7-11.

60. De Souza E, de Lira DP, de Queiroz AC, da Silva DJ, de Aquino AB, Mella EA, et al. The antinociceptive and anti-inflammatory activities of caulerpin, a bisindole alkaloid isolated from seaweeds of the genus Caulerpa. Mar Drugs 2009;7:689-704.

61. Güven KC, Percot A, Sezik E. Alkaloids in marine algae. Mar Drugs 2010;8:269-84.

62. De Oliveira AL, da Silva DB, Lopes NP, Debonsi HM. Chemical constituents from red algae Bostrychia radicans (Rhodomelaceae): New amides and phenolic compounds. Quim Nova 2012;35:2186-8.

63. Wiemer DE, Idler DD, Fenical W. Vidalols A and B, new antiinflammatory bromophenols from the caribbean marine red alga Vidalia obtusaloba. Experientia 1991;47:851-3.

64. Piotrowska Niczyporuk A, Bajguz A. The effect of natural and synthetic auxins on the growth, metabolite content and antioxidant response of green alga Chlorella vulgaris (Trebouxiophyceae). Plant Growth Regul 2014;73:57-66. 